O. Tymochko', V. Larin ${ }^{2}$

${ }^{1}$ Kreditech Holding, Hamburg, Germany

${ }^{2}$ Ivan Kozhedub Kharkiv National Air Force University, Kharkiv

\title{
INVESTIGATION OF THE MECHANISM FOR MEDIAN IMAGE FILTERING IN COMPUTER SYSTEMS AND SPECIAL PURPOSE NETWORKS
}

A successful solution to solve an impulse noise is to use median filtration proposed by John Tuke in 1971 for the analysis of economic processes. It should be noticed that median filtration is a heuristic processing method, its algorithm is not a mathematical solution to a strictly formulated problem. Therefore, the researchers pay much attention to the analysis of the image effectiveness processing on its basis and comparison with other methods.

When applying a median filter, each image pixel is sequentially processed. For median filtration, a twodimensional window (filter aperture) is used, usually has a central symmetry, with its center located at the current filtration point. The dimensions of the aperture are among the parameters that are optimized in the process of analyzing the algorithm efficiency. Image pixels, that appear within the window, form a working sample of the current step.

However median filtering smoothens the image borders to a lesser degree than any linear filtering. The mechanism of this phenomenon is very simple and is as follows. Assume that the filter aperture is near the boundary separating the light and image's dark areas, with its center located in the dark area. Then, most likely, the work sample will contain more elements with small brightness values, and, consequently, the median will be among those elements of the work sample that match this area of the image. The situation changes to the opposite, if the aperture center is shifted to the region of higher brightness. But this means the presence of sensitivity in the median filter to brightness variations.

Keywords: median image filtering, element, level, redundancy, impulse noise.

\section{Introduction}

Problem statement. It is known that a color image requires at least three numbers per pixel to accurately convey its color. The method chosen to represent the brightness and color is called the color space [1]. All color spaces can be listed from the RGB space that can be obtained from the camera or scanner. The red, green, and blue are the main components of the colors represent three dimensions of this space. RGB space is well suited for computer graphics, because it uses these three components for color formation [2]. However, RGB space is not very effective when it comes to real images. The fact is that to save the color of an image, you need to know and store all three components of the RGB, and the if one of them is missing, it will greatly distort the visual image representation. Also, when processing images in RGB space, it is not always convenient to perform any pixel conversion, because, in this case, it will be necessary to list all three values of the RGB component and write back. This greatly reduces the performance of various image processing algorithms. For these and other reasons, many video standards use brightness and two signals that carry information about the red and blue components of the signal, as a color model other than $\mathrm{RGB}$. The most famous among such spaces is $\mathrm{YCbCr}$ [3].

It is known that human eyes are less sensitive to color, than to their brightness. In the RGB color space, all three components are considered equally important, and they are usually stored with the same resolution. However, you can display a color image more efficiently, separating the brightness from color information and presenting it with a higher resolution than color.

Often, all images have a lot of small details that greatly impede image processing, and may also result in some algorithms that are not working correctly, such as contour selection. Therefore, there is a need for preprocessing images that reduces the amount of small parts. Usually Gauss filter [4] is used to solve such problems.

Analysis of the last publications. A lot of researchers have compared features noise affecting the pixels in image is Gaussian in nature and uniformly deters information pixels in image irrespective of their intensity values. This behaviour of noise can also be identified as Additive White Gaussian Noise. As a result of research is novel attempt is made by incorporating the Markov Random Field based Energy Minimization based objective/fitness function for imparting adaptive image denoising using metaheuristic intelligence, as shown in [5].

Computer vision is nowadays is one of the promising and evolving areas in information technology. Image processing is increasingly used in several applications such as automotive, medical or aerospace. Every computer vision application involves capturing several images with the help of camera. Image acquisition, im- 
age transmission $\&$ image security are the three important aspects of image processing system. However, the comparison in [6] does not include of complete image processing system including improved median filtering with better PSNR and operating frequency.

In [7], the image encryption algorithm using block-based scrambling and image filtering was proposed. The main idea of the encryption algorithm is to utilize image filtering to permutate and diffuse plainimages. Using the linear relation, we build a codebook containing $(M \times N+1)$ pairs of cipher-images and the corresponding plain-images, where $\mathrm{M} \times \mathrm{N}$ is the size of plain-images. The proposed codebook attack indicates that the encryption algorithm is insecure.

Another study on the comparison of methods do not consider any prior to extend the accuracy of the depth map. Ultimately, even the improved depth map might lack the accurate structure of the object was conducted in [8]. They The improved performance of guided filters has been ranked against the depth maps of synthetic and real image sequences where the corresponding scenes have diverse range of geometrical complexities.

In [9] was performed developed an Image Filtering and Labelling Assistant (IFLA) system to expedite the most time-consuming portion of this process. This system supplies object-marked images to help researchers identify and label those that are useful. Initial evaluations showed that IFLA is more exact than manual methods.

Due to varrying imaging principles and interwined complexity of structures, different types of imafes must be combined, as single-modality images may only provide limited information was proposed in [10]. A multimodal image fusion method that integrates multimodal images having low resolution with reduced computational complexity to improve the accuracy of target recognition and for providing a basis for research, is not used.

Resolution is one of the most important parameters of low-light-level (LLL) image intensifiers, reflecting the target detection performance of assembled night vision devices under 10-3 to 10-1 $1 \mathrm{x}$ dark environment. The traditional methods of measuring this parameter are classified into subjective evaluation and objective test. The disadvantages of subjective evaluation are strong subjectivity and low accuracy, while the traditional objective test method shows the weaknesses of excessive human intervention and large time consumption. It was described in [9].

The research aims and objectives. The aim of article is to investigation of the mechanism for median image filtering in computer systems and special purpose networks.

The objective of article is the process of a median image filtering for in computer systems and special purpose networks.

\section{Statement of basic materials}

Filling the values operation of the median filter for the pixel value of the elementary object will correspond to the following expression:

$$
y_{k}=x_{i, j},\left\{\begin{array}{l}
i=k-\left\lfloor\frac{k}{m}\right\rfloor \cdot m, \\
j=\left\lfloor\frac{k}{m}\right\rfloor, k=0 . .(2 m+1)^{2}-1
\end{array}\right\},
$$

Here are

$x_{i, j}$ - the value of the pixel of the original image with coordinates $i$ and $j$;

$y_{k}$ - a set of pixels' values included in the function's structure of the median filter;

$k$ - pixel values' index of the median filter;

$m$ - the radius of the median filter.

Fig. 1 [11] gives an explanation of the performed medial filtering operations, and shows the location of the median filter elements' values for radius values. In this case, the final, resulting value of the median filter will be obtained after sorting the found items by their value.

$$
\left[\begin{array}{l}
\left\{y_{k}^{\prime}\right\}=\left\{y_{0}^{\prime} \geq y_{1}^{\prime} \geq y_{2}^{\prime} \geq \ldots \geq y^{\prime}{ }_{(2 m+1)^{2}-1}\right\} \\
\left\{y_{k}^{\prime}\right\}=\left\{y_{0}^{\prime} \leq y_{1}^{\prime} \leq y_{2}^{\prime} \leq \ldots \leq y_{(2 m+1)^{2}-1}^{\prime}\right\}
\end{array}\right.
$$

here are

$\left\{y_{k}^{\prime}\right\}$ - a declinely sorted collection of the values of the median filter's function;

$y_{0}^{\prime}-$ the pixel's first value in the sorted set structure of all values of the median filter's function;

$y_{1}^{\prime}$ - the pixel's second value in the sorted set structure of all values of the median filter's function;

$(2 m+1)^{2}-1$ - the maximum number of median filter's elements for a rectangular window;

$m-$ the median filter's radius.

The value $y_{\frac{(2 m+1)^{2}-1}{2}}^{\prime}$ will be the median value of the median filter. Therefore, it will be the solution of processing one pixel. In order to find the following values, the window function shifts to the right and when the image border reaches down one pixel down and moves from the original zero position on the horizontal axis until the image boundary is reached. In the end, an array containing the found values of the median filter 
will be formed [12]. In this work, the median filtering is implemented using the software package Mathcad 15.

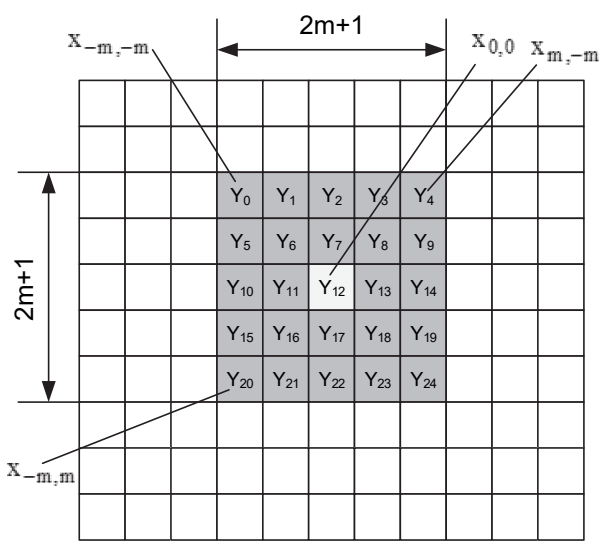

Fig. 1. Median filtering rectangular window

The example below describes the use of a rectangular median filter matrix, but applying a rectangular window has errors in finding the correct mean value. To minimize this error, use the window in the form of a "snowflake", which is given by the formula:

$$
y_{k}=x_{i, j},\left\{\left[\begin{array}{c}
|i|=|j|,|i| \leq m \\
|i| \leq m, j=0 \\
|j| \leq m, i=0
\end{array}\right\}\right.
$$

here is

$\left\{\left[\begin{array}{c}|i|=|j|,|i| \leq m ; \\ |i| \leq m, j=0 ; \\ |j| \leq m, i=0 .\end{array}\right\}\right.$ - the condition for selecting the

elements of the median filter for the window in the "snowflakes" form;

The explanations for median filtering for windows in the "snowflakes" form and in the form of a circle are shown in fig. 2 and fig. 3 [12] respectively. Each of these windows gives good results in analyzing individual image components, so in order to verify the results it is suggested to use the average value obtained as a result of separate three operations.

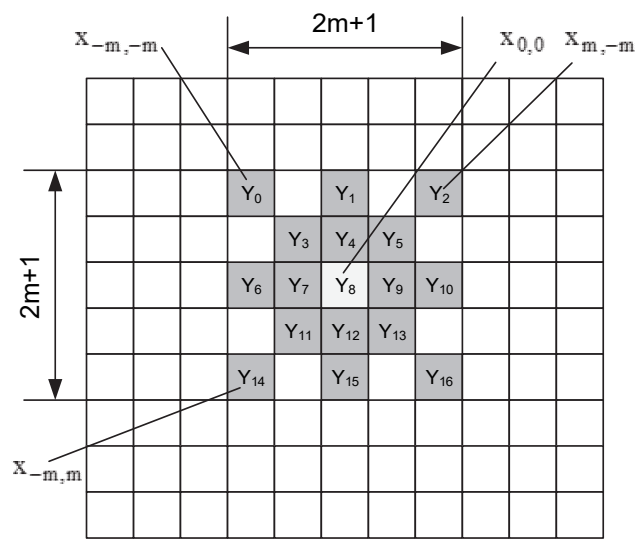

Fig. 2. Median filtering in the form of a "snowflake"

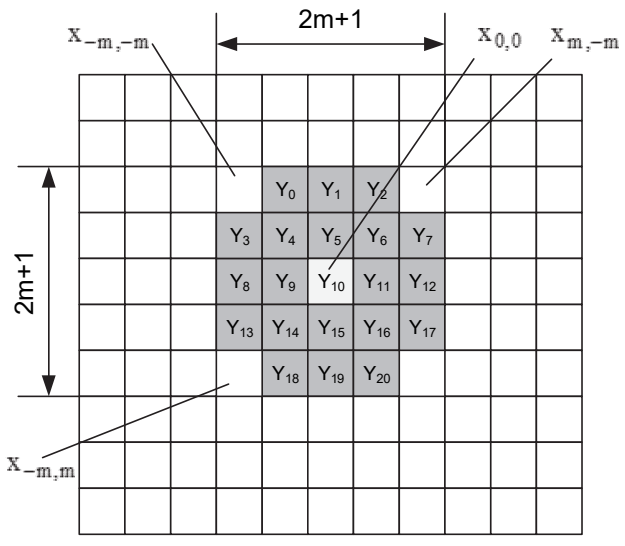

Fig. 3. Median filtering in a circle-shaped window

Examples of this algorithm's work for an image having an average saturation with small details given in Fig. 4 [13], at various values of the size and type of filter aperture. To determine the best result, the peak to noise ratio of each image is calculated.

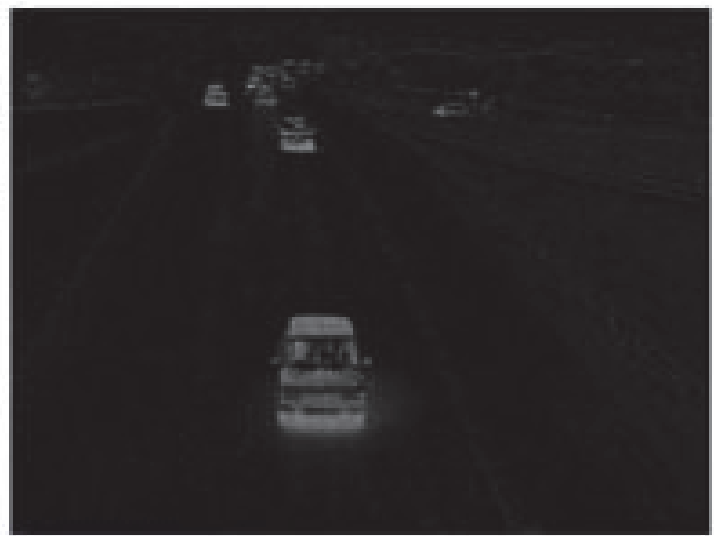

Fig. 4.Image distorted by impulse noise

The Gauss filter is based on the Gaussian functions of one and two variables:

$$
\begin{aligned}
& G(x)=\frac{1}{\sqrt{2 \pi \sigma^{2}}} \cdot e^{-\frac{x^{2}}{2 \sigma^{2}}}, \\
& G(x, y)=\frac{1}{\sqrt{2 \pi \sigma^{2}}} \cdot e^{-\frac{x^{2}+y^{2}}{2 \sigma^{2}}},
\end{aligned}
$$

here are

$\sigma$ - standard deviation of normal distribution, which specifies the "blurring degree" of the processed image;

$x, y$ - distance from the starting point (pixel) to the point for which the value of the function is calculated vertically and horizontally, respectively.

In the general case, Gauss distribution has the form shown on fig. 5 [8]: 


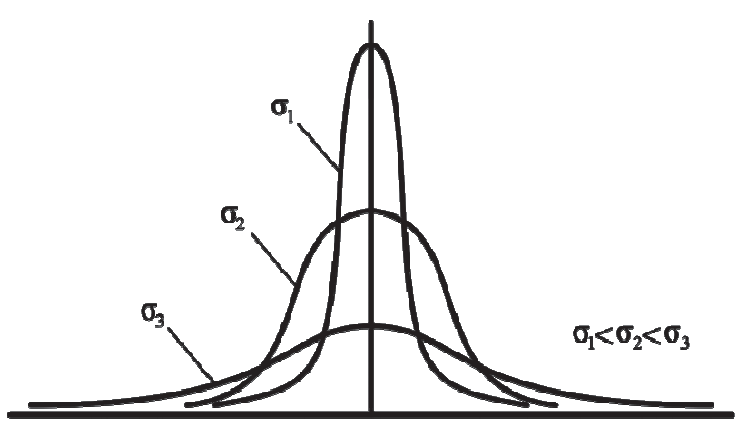

Fig. 5. The Gaussian distribution for different values

Thus, based on the Gauss function, a convolution matrix is constructed, for which the average weighted value of the neighboring pixels is calculated for each pixel of the image:

$$
F_{m, n}=\sum_{i=-k}^{k} \sum_{j=-k}^{k} r_{m+i, n+j} G(i, j),
$$

here is

$k-$ the dimension of the matrix of convolution.
As a result of applying the Gaussian filter, all distorted pixels (pixels, which brightness is very different from the brightness of the neighboring pixels) take an average value, noise is suppressed, and the contours of the objects are emphasized, which is very useful in recognizing images on digital images.

In this work, the Gauss filter is implemented by using the software package Mathcad 15.

\section{Conclusions}

1. For best results it is expedient to use for each image type your template size, as well as its type.

2. For the first type of image, it is best to choose a filter size of 5 pixels.

3. For all image types, regardless of the filter's size, the best result can be obtained by using a "snowflake" pattern.

4. An increase in the size of the filter is not feasible because it leads to an increase in the algorithm's running time and a "tampering" of the image.

\section{References}

1. Yevseiev, S., Ahmed Abdalla, Osiievskyi, S., Larin, V. and Lytvynenko, M. (2020), Development of an advanced method of video information resource compression in navigation and traffic control systems, EUREKA: Physics and Engineering, No. 5, pp. 31-42. https://doi.org/10.21303/2461-4262.2020.001405.

2. Ruban, I., Smelyakov, K. and Bolohova, N. (2018), Method of neural network recognition of ground-based air objects, Proceedings of 2018 IEEE 9th International Conference on Dependable Systems, Services and Technologies DESSERT 2018, pp. 589-592. https://doi.org/10.1109/DESSERT.2018.8409200.

3. Sumtsov, D., Osiievskyi, S. and Lebediev, V. (2018), Development of a method for the experimental estimation of multimedia data flow rate in a computer network, Eastern-European Journal of Enterprise Technologies, Vol. 2, No. 2(92), pp. 56-64. https://doi.org/10.15587/1729-4061.2018.128045.

4. Himanshu Singh, Sethu Venkata, Raghavendra Kommuri, Anil Kumar and Varun Bajaj. (2021), A new technique for guided filter based image denoising using modified cuckoo search optimization, Expert Systems with Applications, Volume 176, 15 August 2021. https://doi.org/10.1016/j.eswa.2021.114884.

5. Tkachov, V., Tokariev, V., Radchenko, V. and Lebediev, V. (2017), The Problem of Big Data Transmission in the Mobile "Multi-Copter - Sensor Network" System, Control, Navigation and Communication Systems, No. 2, pp. 154-157.

6. Pavlenko, M., Timochko, A., Korolyuk, N. and Gusak, M. (2014), Hybrid model of knowledge for situation recognition in airspace, Automatic Control and Computer Sciences, Vol. 48, No. 5, pp. 257-263. https://doi.org/10.3103/ S0146411614050083.

7. Gonzales, R.C. and Woods, R.E. (2002), Digital image processing, Prentice Inc. Upper Saddle River, New Jersey, 779 p.

8. Sandeep K. Shelke, Sanjeet K. Sinha and Govind Singh Patel (2021), Development of complete image processing system including image filtering, image compression \& image security. https://doi.org/10.1016/j.matpr.2021.06.154.

9. Feng Yu, Xinhui Gong, Hanpeng Li and Shihong Wang (2021), Differential cryptanalysis of image cipher using blockbased scrambling and image filtering, Information Sciences, Vol. 554, pp. 145-156. https://doi.org/10.1016/j.ins.2020.12.037.

10. Usman Ali, Ik Hyun Lee and Muhammad Tariq Mahmood (2021), Guided image filtering in shape-from-focus: A comparative analysis, Pattern Recognition, Vol. 111. https://doi.org/10.1016/j.patcog.2020.107670.

11. Tianyu Xi, Jiangning Wang, Huijie Qiao, Congtian Lin and Liqiang Ji (2021), Image Filtering and Labelling Assistant (IFLA): Expediting the analysis of data obtained from camera traps, Ecological Informatics, Vol.64. https://doi.org/10.1016/j.ecoinf.2021.101355.

12. Pavlenko, M., Kolmykov, M., Tymochko, O., Khmelevskiy, S. and Larin, V. (2020), Conceptual Basis of Cascading Differential Masking Technology, 2020 IEEE 11th International Conference on Dependable Systems, Services and Technologies (DESSERT). https://doi.org/10.1109/dessert50317.2020.9125024.

13. Tyurin, V., Martyniuk, O., Mirnenko, V., Open'ko, P. and Korenivska, I. (2019), General Approach to Counter Unmanned Aerial Vehicles, 2019 IEEE 5th International Conference Actual Problems of Unmanned Aerial Vehicles Developments (APUAVD). https://doi.org/10.1109/apuavd47061.2019.8943859. 


\title{
Список літератури
}

1. Yevseiev S., Ahmed Abdalla, Osiievskyi S., Larin V., Lytvynenko M. Development of an advanced method of video information resource compression in navigation and traffic control systems. EUREKA: Physics and Engineering. 2020. No. 5. P. 31-42. https://doi.org/ 10.21303/2461-4262.2020.001405.

2. Ruban I., Smelyakov K., Bolohova N. Method of neural network recognition of ground-based air objects. Proceedings of 2018 IEEE 9th International Conference on Dependable Systems, Services and Technologies DESSERT 2018. 2018. P. $589-592$. https://doi.org/10.1109/DESSERT.2018.8409200.

3. Sumtsov D., Osiievskyi, S., Lebediev, V. Development of a method for the experimental estimation of multimedia data flow rate in a computer network. Eastern-European Journal of Enterprise Technologies. 2018. Vol. 2. No. 2(92). P. 56-64. https://doi.org/10.15587/1729-4061.2018.128045.

4. Himanshu Singh, Sethu Venkata, Raghavendra Kommuri, Anil Kumar, Varun Bajaj. A new technique for guided filter based image denoising using modified cuckoo search optimization. Expert Systems with Applications. 2021. Vol. 176. 15 August 2021. https://doi.org/10.1016/j.eswa.2021.114884.

5. Tkachov V., Tokariev V., Radchenko V., Lebediev V. The Problem of Big Data Transmission in the Mobile "MultiCopter - Sensor Network" System. Control, Navigation and Communication Systems. 2017. No. 2. P. 154-157.

6. Pavlenko M., Timochko A., Korolyuk N., Gusak M. Hybrid model of knowledge for situation recognition in airspace. Automatic Control and Computer Sciences. 2014. Vol. 48. No. 5. P. 257-263. https://doi.org/10.3103/S0146411614050083.

7. Gonzales R.C., Woods R.E. Digital image processing. New Jersey : Prentice Inc. Upper Saddle River, 2002. 779 p.

8. Sandeep K.Shelke, Sanjeet K.Sinha, Govind Singh Patel. Development of complete image processing system including image filtering, image compression \& image security. 2021. https://doi.org/10.1016/j.matpr.2021.06.154.

9. Feng Yu, Xinhui Gong, Hanpeng Li, Shihong Wang. Differential cryptanalysis of image cipher using block-based scrambling and image filtering. Information Sciences. 2021. Vol. 554. P. 145-156. https://doi.org/10.1016/j.ins.2020.12.037.

10. Usman Ali, Ik Hyun Lee, Muhammad Tariq Mahmood. Guided image filtering in shape-from-focus : A comparative analysis. Pattern Recognition. 2021. Vol. 111. https://doi.org/10.1016/j.patcog.2020.107670.

11. Tianyu Xi, Jiangning Wang, Huijie Qiao, Congtian Lin, Liqiang Ji. Image Filtering and Labelling Assistant (IFLA): Expediting the analysis of data obtained from camera traps. Ecological Informatics. 2021. Vol.64. https://doi.org/10.1016/j.ecoinf.2021.101355.

12. Pavlenko M., Kolmykov M., Tymochko O., Khmelevskiy S., Larin V. Conceptual Basis of Cascading Differential Masking Technology. 2020 IEEE 11th International Conference on Dependable Systems, Services and Technologies (DESSERT). https://doi.org/10.1109/dessert50317.2020.9125024.

13. Tyurin V., Martyniuk O., Mirnenko V., Open'ko P., Korenivska I. General Approach to Counter Unmanned Aerial Vehicles. 2019 IEEE 5th International Conference Actual Problems of Unmanned Aerial Vehicles Developments (APUAVD). https://doi.org/10.1109/apuavd47061.2019.8943859.

Received by Editorial Board 18.08.2021 Signed for Printing 14.09.2021

\section{Відомості про авторів:}

Тимочко Олександр Олександрович

кандидат технічних наук

інженер фірми “Kreditech"

Гамбург, Німеччина

https://orcid.org/0000-0003-0424-0426

\section{Information about the authors:}

Oleksandr Timochko

Candidate of Technical Sciences

Expert Quality Assurance Engeneer of Kreditech Holding, Hamburg, Germany

https://orcid.org/0000-0003-0424-0426

\section{Volodymyr Larin}

Candidate of Technical Sciences Associate Professor

Senior Lecturer of Ivan Kozhedub Kharkiv

National Air Force University,

Kharkiv, Ukraine

https://orcid.org/0000-0003-0771-2660

Харків, Україна

https://orcid.org/0000-0003-0771-2660

\section{ДОСЛІДЖЕННЯ МЕХАНІЗМУ ФІЛЬТРАЦІЇ МЕДІАННИХ ЗОБРАЖЕНЬ В КОМП'ЮТЕРНИХ СИСТЕМАХ І МЕРЕЖАХ СПЕЦІАЛЬНОГО ПРИЗНАЧЕННЯ}

\author{
О.О. Тимочко, В.В. Ларін
}

Успішним рішенням проблеми імпульсного шуму є використання медіанної фільтрації, запропонованої Джоном Тьюком. Слід зазначити, що медіанна фільтрація - ие евристичний метод обробки, ї̈ алгоритм не є математичним ріменням строго сформульованої задачі. Тому велику увагу дослідники приділяють аналізу ефективності обробки зображень на його основі і порівняно з іншими методами. При застосуванні медіанного фільтра кожен піксель зображення обробляється послідовно. Для медіанної фільтрачії використовується двовимірне вікно (апертура фільтру), 
зазвичай має центральну симетрію, з центром, розтамованим в поточній точці фільтрації. Розміри апертури входять в число параметрів, які оптимізуються в прочесі аналізу ефективності алгоритму. Пікселі зображення, щуо з'являються у вікні, утворюють робочий зразок поточного кроку.

Однак медіанна фільтрація згладжуе кордони зображення в меншій мірі, ніж будь-яка лінійна фільтрація. Механізм иього явища дуже простий і полягає в наступному. Припустимо, що апертура фільтру знаходиться поруч з кордоном, що розділяє світлі і темні області зображення, з иентром в темній області. Тоді, швидие за все, робочий зразок буде містити більше елементів з невеликими значеннями яскравості, $i$, отже, медіана буде серед тих елементів робочого зразка, які відповідають цій області зображення. Ситуація змінюється на протилежну, якщо центр апертури змішується в область більшої яскравості. Але це означає наявність чутливості в медіанному фільтрі до варіацій яскравості.

Ключові слова: медіанна фільтрація зображення, елемент, рівень, надмірність, імпульсний шум.

\title{
ИССЛЕДОВАНИЕ МЕХАНИЗМА ФИЛЬТРАЦИИ МЕДИАННЫХ ИЗОБРАЖЕНИЙ В КОМПЬЮТЕРНЫХ СИСТЕМАХ И СЕТЯХ СПЕЦИАЛЬНОГО НАЗНАЧЕНИЯ
}

\author{
А.А. Тимочко, В.В. Ларин
}

Медианная фильтрация - это эвристический метод обработки, ее алгоритм не является математическим решением строго сформулированной задачи. Поэтому большое внимание было уделено анализу эффективности обработки видеоинформачионного ресурса на его основе и сравнению с другими методами. При применении медианного фильтра каждый пиксель изображения обрабатывается последовательно. Для медианной фильтрации используется двумерное окно (апертура фильтра), обычно имеющее иентральную симметрию, с иентром, расположенным в текущей точке фильтрачии. Размеры апертуры входят в число параметров, которые оптимизируются в процессе анализа эффективности алгоритма. Пиксели изображения, появляющиеся в окне, образуют рабочий образец текущего шага.

Однако медианная фильтрация сглаживает границь изображения в меньшей степени, чем любая линейная фильтрация. Механизм этого явления очень прост и заключается в следующем. Предположим, что апертура фильтра находится рядом с границей, разделяющей светлье и темные области изображения, с центром в темной области. Тогда, скорее всего, рабочий образеи будет содержать больше элементов с небольшими значениями яркости, и, следовательно, медиана будет среди тех элементов рабочего образиа, которые соответствуют этой области изображения.

Ключевые слова: медианная фильтрачия изображения, элемент, уровень, избыточность, импульсный шум. 